\title{
A Single Dose of Lysergic Acid Diethylamide Influences Gene Expression Patterns within the Mammalian Brain
}

\author{
Charles D. Nichols, Ph.D., and Elaine Sanders-Bush, Ph.D.
}

Hallucinogenic drugs such as lysergic acid diethylamide (LSD) have profound effects on humans including hallucinations and detachment from reality. These remarkable behavioral effects have many similarities to the debilitating symptoms of neuropsychiatric disorders such as schizophrenia. The effects of hallucinogens are thought to be mediated by serotonin receptor activation; however, how these drugs elicit the unusual behavioral effects remains largely a mystery, despite much research. We have undertaken the first comprehensive analysis of gene expression influenced by acute LSD administration in the mammalian brain. These studies represent a novel approach to elucidate the mechanism of action of this class of drugs. We have identified a number of genes that are predicted to be involved in the processes of synaptic plasticity, glutamatergic signaling and cytoskeletal architecture. Understanding these molecular events will lead to new insights into the etiology of disorders whose behavioral symptoms resemble the temporary effects of hallucinogenic drugs, and also may ultimately result in new therapies.

[Neuropsychopharmacology 26:634-642, 2002] (C) 2002 American College of Neuropsychopharmacology. Published by Elsevier Science Inc.
KEY WORDS: Serotonin receptor, Hallucinogen, LSD, prefrontal cortex, $m R N A, D N A$ microarray

\section{INTRODUCTION}

Lysergic acid diethylamide (LSD) is an hallucinogenic drug that transiently but powerfully alters human perception, behavior, and mood at extremely low doses. Certain aspects of the behavior elicited by acute doses

From the Department of Pharmacology, Vanderbilt University School of Medicine, Nashville, TN 37232.

Address correspondence to: Elaine Sanders-Bush, Ph.D., Department of Pharmacology, Vanderbilt University School of Medicine. Nashville, TN 37232, Tel.: (615) 936-1685, Fax: (615) 343-6532, E-mail: Elaine.Bush@mcmail.vanderbilt.edu

Received June 29, 2001; revised October 11, 2001; accepted October 20, 2001

Online publication: 11/6/01 at www.acnp.org/citations/ Npp110601200. of LSD closely resemble symptoms of mental disorders such as schizophrenia (Breier 1995). Despite extensive research over the past four decades, the mechanism of action of hallucinogenic drugs still largely remains a mystery. The behavioral effects of LSD are believed to arise in part from agonist activity at the $5-\mathrm{HT}_{2 \mathrm{~A}}, 5-\mathrm{HT}_{2 \mathrm{C}}$, and 5- $\mathrm{HT}_{1 \mathrm{~A}}$ receptor subtypes (Burris et al. 1991; KrebsThomson et al. 1998; Titeler et al. 1988), but if, and how, these interactions affect cognitive functions remains unknown. In addition to actions at serotonin receptors, LSD has high affinity for dopamine receptors and has been shown to act as an agonist at these receptors (Giacomelli et al. 1998; Watts et al. 1995). Because LSD is a unique ligand that can simultaneously bind to serotonin and dopamine receptor subtypes implicated in both normal and abnormal human behaviors, it is an excellent tool for probing the biochemical basis for behavior.

Simply increasing brain levels of serotonin, however, does not produce hallucinogenic effects. Recent work has demonstrated that while LSD binds to the same re- 
ceptor sites as the endogenous ligand serotonin, it has the capacity to activate different intracellular signaling cascades (Backstrom et al. 1999). Because intracellular signaling cascades influence gene expression, LSDinduced signaling events within cells may inappropriately alter gene expression, which in turn may lead to changes in the physiological status of the neurons, ultimately altering the processes of cognition. Certain behavioral effects of LSD resemble paranoid schizophrenia in humans. This particular subset of mood alterations occurs within the "second phase ... of the LSD experience" as defined by Freedman, and may be specific for LSD (Freedman 1984). These delayed "second phase" effects could result from transient changes in gene expression. Thus, identifying and characterizing these genes could prove to be important in understanding mechanisms underlying how hallucinogens such as LSD alter behavior. In addition, understanding these mechanisms may lead to the identification of novel therapeutic targets for treatment of mental disorders.

We took a broad approach to investigating and identifying genes that are altered by an acute dose of LSD in the mammalian brain. First, we investigated the expression of the mRNAs of the 5-HT receptor subtypes thought to mediate hallucinogenic effects in animal models (5- $\left.\mathrm{HT}_{1 \mathrm{~A}, 2 \mathrm{~A}, 2 \mathrm{C}}\right)$, as well as, specific gene expression of immediate early genes predicted to be affected by LSD. Next, we performed a DNA microarray screen to identify gene expression influenced by LSD at a more global level. For each gene identified, expression levels were determined in three regions of the rat brain: prefrontal cortex, hippocampus, and midbrain/thalamus.

\section{MATERIALS AND METHODS}

\section{Animals}

Male Sprague-Dawley rats (250-275g) were purchased from Harlan and maintained for at least one week prior to use. Rats were given ad libitum access to food and water and maintained on a $12 \mathrm{~h}$ light/dark cycle. All procedures were carried out in accordance with the National Institutes of Health guide for the care and use of laboratory animals (NIH publication No. 8023, revised 1978) and were approved by the Vanderbilt Animal Care and Use Committee.

\section{Drug Treatment and Tissue Preparation}

$(+)$-LSD tartrate was obtained from NIDA and dissolved at a concentration of $1.0 \mathrm{mg} / \mathrm{ml}$ in sterile water. Four rats were administered $1.0 \mathrm{mg} / \mathrm{kg}$ LSD i.p., and four rats were simultaneously administered i.p. saline. After 90 min the animals were decapitated. The brains were removed and the prefrontal cortex, hippocampus and midbrain were quickly dissected, frozen in liquid nitrogen, and stored at $-80^{\circ} \mathrm{C}$ until processing. Total RNA was extracted from the tissue of four animals pooled per treatment group. Pooling of the tissues should help average out differences in individual responses to the drug. RNA purification was performed using Tri-Reagent ${ }^{\circledR}$ (Molecular Research Center; Cincinnati, $\mathrm{OH})$. This total RNA was used as target in RNase protection assays with probe fragments specific to each gene tested. A 90-min time point was chosen because preliminary studies had shown differential expression for $c$-fos both at the mRNA and protein level at this time.

\section{RNase Protection}

RNase protection involves hybridization of an antisense radiolabeled RNA (probe) to a specific gene (target) in solution. A single stranded specific RNase was added to the mixture after hybridization to degrade all single stranded RNA, so that only probe hybridized to target remains. A probe representing cyclophilin, a standard internal control not expected to be influenced by treatments, was simultaneously hybridized and used as an internal control to normalize for variations in RNA levels. Reaction products were separated on a polyacrylamide gel, exposed to a phosphorimager plate, and the bands quantified by densitometry.

To generate radiolabeled probe, gene specific fragments were isolated by RT-PCR from rat brain total RNA with oligonucleotide primers specific for the gene of interest using the Titan ${ }^{\mathrm{TM}}$ One Step RT-PCR kit reagents and protocols from Roche Molecular Biochemicals (Indianapolis, IN) (Table 1) and reamplified with primers containing a T7 RNA polymerase binding site on the antisense strand. Probe sequence was verified by ABI Prism sequencing protocols. [ $\left.{ }^{32} \mathrm{P}\right]-\mathrm{CTP}$ (NEN; Boston, MA) radiolabeled antisense RNA probe was prepared by in vitro synthesis from DNA template, prepared as described above, using the MAXIscript ${ }^{\mathrm{TM}}$ kit reagents and protocols from Ambion (Austin, TX). RNase protection assays were performed using the RPA III ${ }^{\mathrm{TM}}$ kit reagents and protocols from Ambion. Total probe used in each reaction was 70,000 cpm for gene specific RNA, and $1400 \mathrm{cpm}$ for the internal standard, cyclophilin, with $10 \mu \mathrm{g}$ of total RNA per reaction. After electrophoresis the gels were dried on Whatman paper and exposed to phosphoimager plates (Molecular Dynamics, Sunnyvale CA). Bands were visualized using a Molecular Dynamics 445 SI Phosphoimager. Band densitometry analysis was performed with NIH Image 1.6.1 software on MacOS.

\section{DNA Microarray Screen}

RNA isolated from the prefrontal cortex of LSD and saline treated rats was re-purified using the RNeasy kit 
Table 1. Gene Specific Primers for Probe Preparation

\begin{tabular}{lll}
\hline Gene & \multicolumn{1}{c}{ Forward Primer $\left(\mathbf{5}^{\prime} \rightarrow \mathbf{3}^{\prime} \mathbf{)}\right.$} & \multicolumn{1}{c}{ Reverse Primer $\left(\mathbf{5}^{\prime} \rightarrow \mathbf{3}^{\prime} \mathbf{)}\right.$} \\
\hline ania3 & ACACCTTCAAACAAACATTAGGTAA & TACTATCATATAAAGGCCCAATCGT \\
arc & TCTGCAGTACAGTGAGGGTACG & CTGGTACAGGTCCCGCTTACG \\
$c-f o s$ & AACAATACCTACTGTGTTCCTG & GCATGATCAGTTACATGACAAT \\
I $\boldsymbol{\beta} a$ & CTCCATGAAGGACGAGGATTACG & GGTCAGTGTCTTCTCTTCATGGATG \\
$k r o x-20$ & AGTGAGCACAGTTTAGCCCTGG & ACATTGCACTTCCGTTCGTTCTCT \\
NOR1 & CGGTTCAACATTCCGTGTTTGT & AGGCAAAGCGATTACAATAGAACG \\
$s g k$ & GAGCCGTTGGTGTTCATGTTAA & GACATGTAACCCAATATTGTGATC \\
\hline
\end{tabular}

from Qiagen (Valencia, CA) and used as template for the BioArray High Yield RNA Transcript Labeling Kit (Enzo Diagnostics; Farmingdale, NY) as per the manufacturer's instructions. Biotin labeled cRNA was provided to Research Genetics (Huntsville, AL) for hybridization and analysis with the Affymetrix rat U34A array set. The GeneChip ${ }^{\circledR}$ Analysis software package from Affymetrix was employed by Research Genetics to identify statistically significant changes in gene expression. Genes identified in this screen were considered candidates for differential expression until confirmed by RNase protection experiments.

\section{RESULTS}

\section{Serotonin Receptor mRNA Levels Are Unchanged by Acute LSD}

The expression of the $5-\mathrm{HT}_{1 \mathrm{~A}}, 5-\mathrm{HT}_{2 \mathrm{~A}}$, and $5-\mathrm{HT}_{2 \mathrm{C}}$ receptors, subtypes thought to play major roles in the mechanism of action of hallucinogenic drugs, was tested after LSD administration. In control animals, endogenous $5 \mathrm{HT}_{2 \mathrm{~A}}$ receptor mRNA levels were about threefold higher in the prefrontal cortex than in either the hippocampus or midbrain (Figure 1). Control $5 \mathrm{HT}_{2 \mathrm{C}}$ receptor mRNA levels were approximately twofold higher in the midbrain than in the hippocampus or prefrontal cortex (Figure 1), while endogenous $5 \mathrm{HT}_{1 \mathrm{~A}}$ receptor mRNA levels were twofold higher in the hippocampus than in either the prefrontal cortex or midbrain (Figure 1). There was no detectable effect of acute LSD on any of these receptors; mRNA expression levels were virtually identical to those of control animals in all brain regions examined (Table 2). This finding indicates that acute LSD does not invoke receptor mRNA downregulation as a mechanism to inactivate signaling of these receptors.

\section{Acute LSD Induces Immediate Early Gene Expression}

Acute LSD administration $(1.0 \mathrm{mg} / \mathrm{kg}, 90 \mathrm{~min})$ induced $c$-fos in all specific areas of the brain examined by about twofold (Figure 2, Panel A, and Figure 3, Panel A). The expression of arc was induced fivefold in the prefrontal cortex of rats treated with LSD compared with control levels (Figure 2, Panel B, and Figure 3, Panel B). This dramatic change was region-specific; arc expression levels were relatively unchanged in the hippocampus and were undetectable in the midbrain (Figure 3, Panel B).

\section{DNA Microarray-identified Candidates for Differential Expression}

The Affymetrix U34A rat array contains sequences representing 8800 genes. Only about 3,500 of them gave positively hybridizing signals, indicating that more than half of the genes represented by the array are not expressed in the rat prefrontal cortex at levels detectable by this method (Figure 4). A few genes appeared to be downregulated in the array results (Figure 4). Of these, the two furthest away from the slope represent the $32 \mathrm{~S}$ ribosome preRNA and $28 \mathrm{~S}$ ribosome subunits. While these were flagged by the analysis software as significantly repressed, they were not tested in subsequent studies. It may be intriguing to speculate that the drug treatment has effects on general transcription, but we felt that as transcription is a global mechanism, any changes observed in ribosome subunit mRNAs were not likely involved in mechanisms of action of LSD.

Five candidates were identified by microarray screening with the Affymetrix microarray and investigated further: serum glucocorticoid kinase (sgk); Iк $\beta-\alpha$, neuron derived orphan receptor 1 (NOR1); ania3; and krox20. Although microarrays are useful to identify genes differentially expressed, they may not be suitable to define and quantitate expression changes of genes due to different treatment conditions (Watson et al. 2000; Altmann et al. 2001). Therefore, all subsequent verification and expression testing of an identified candidate used RNase protection assays. We chose the RNase protection method over blot-based methods such as Northern analysis because RNase protection is more sensitive and reliable. All five genes identified by microarray analyses of prefrontal cortex RNA were confirmed in the subsequent RNase protection assays; however, the apparent percent increase in the microarrays was much higher than revealed by RNase protection (Table 3 ). 


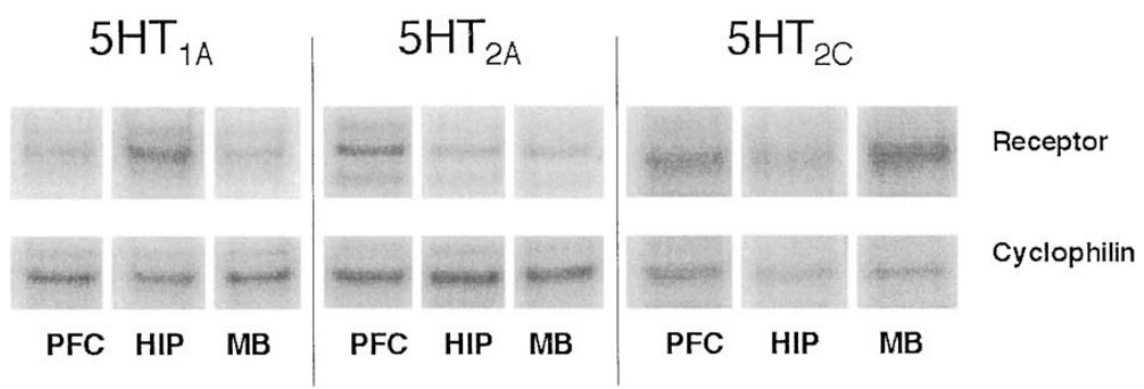

Figure 1. Relative expression of $5-\mathrm{HT}_{1 \mathrm{~A}, 2 \mathrm{~A}, 2 \mathrm{C}}$ receptor mRNA. The expression for the mRNAs of serotonin receptor subtypes believed to play a role in the mechanism of action of hallucinogenic drugs as determined by RNase protection analysis in the prefrontal cortex (PFC), hippocampus (HIP), and midbrain (MB). Acute LSD had no effect on the expression of these genes.
Similar to the results in prefrontal cortex, differential gene expression was found in the midbrain for all genes except Krox-20, which was undetectable in midbrain of both control and LSD-treated rats (Figure 5, Panels A-E). NOR1 and Ania3 expression were unaffected in the hippocampus (Figure 5, Panels C and D), an area that expresses a low density of $5-\mathrm{HT}_{2 \mathrm{~A}}$ receptors.

\section{DISCUSSION}

We have undertaken the first comprehensive analysis of hallucinogen influenced gene expression in the brain using a combination of gene microarrays and RNase protection assays. Seven genes have been identified that are differentially expressed after acute treatment with the hallucinogen LSD. Gene microarrays have great utility to identify candidates for differential expression; however, our results as well as others (Watson et al. 2000; Altmann et al. 2001) show microarrays are not suitable for accurate quantitation of expression levels. Although most of the genes identified in the current microarray screen were confirmed with RNase protection, the magnitude of change was considerably less in the latter assay. The number of candidate genes identified in the microarray screen was surprisingly small, suggesting that relatively minor changes in cellular physiology may lead to marked changes in cognitive function. Consistent with this conclusion, the magnitude of change in levels was generally twofold or less. It is quite likely that a more detailed analysis by in situ hybridization methods will reveal localized regions that exhibit greater differential expression.

Table 2. Serotonin Receptor Gene Expression

\begin{tabular}{lcccc}
\hline & & PFC & HIP & MB \\
\hline $5-H T_{2 A}$ & S & $100 \pm 1$ & $100 \pm 6$ & $100 \pm 1$ \\
& $\mathrm{~L}$ & $97 \pm 2$ & $96 \pm 2$ & $108 \pm 6$ \\
$5-H T_{2 C}$ & $\mathrm{~S}$ & $100 \pm 10$ & $100 \pm 2$ & 100 \\
& $\mathrm{~L}$ & $95 \pm 3$ & $114 \pm 20$ & $102 \pm 5$ \\
$5-H T_{1 A}$ & $\mathrm{~S}$ & $100 \pm 5$ & $100 \pm 1$ & $100 \pm 3$ \\
& $\mathrm{~L}$ & $93 \pm 6$ & $98 \pm 2$ & $94 \pm 1$ \\
\hline
\end{tabular}

The differentially expressed genes after acute LSD treatment encode for a variety of proteins, including immediate early genes (IEGs) such as $c$-fos, which encodes for a nuclear transcription factor that in turn activates multiple downstream genes. The $c$-fos gene is rapidly upregulated by many stimulatory pathways and is often used as a marker to determine general neuronal activation (Kovacs 1998). Levels of $c$-fos increased approximately twofold in all areas of the brain examined in response to acute LSD, suggesting that LSD activates many brain areas. Another nuclear transcription factor

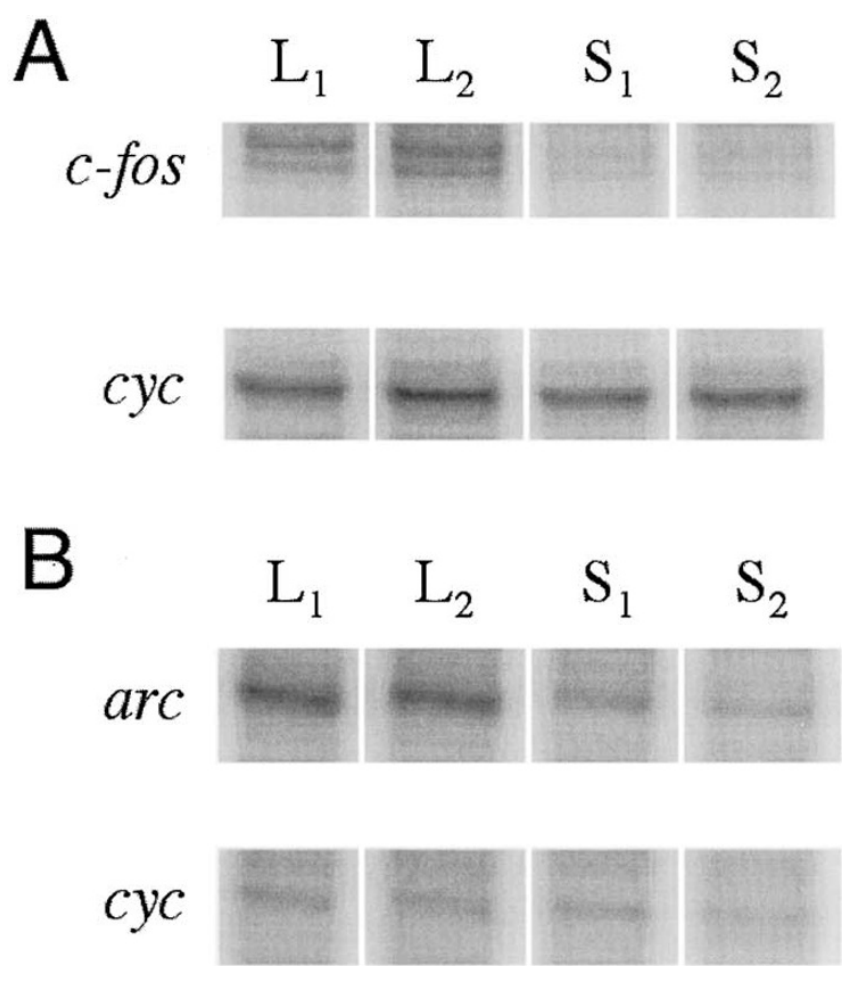

Figure 2. Arc and c-fos expression in the prefrontal cortex. This figure shows the results of RNase protection experiments examining the expression of $c$-fos (Panel A), and arc (Panel B) in the prefrontal cortex. Two independent hybridization reaction products are shown for each treatment condition ( $\mathrm{L}=\mathrm{LSD}$ treated, $\mathrm{C}=$ control). The upper band represents the protected gene specific fragment, the lower band represents the protected internal control, cyclophilin. These bands are quantified by densitometry to obtain expression values. 
A

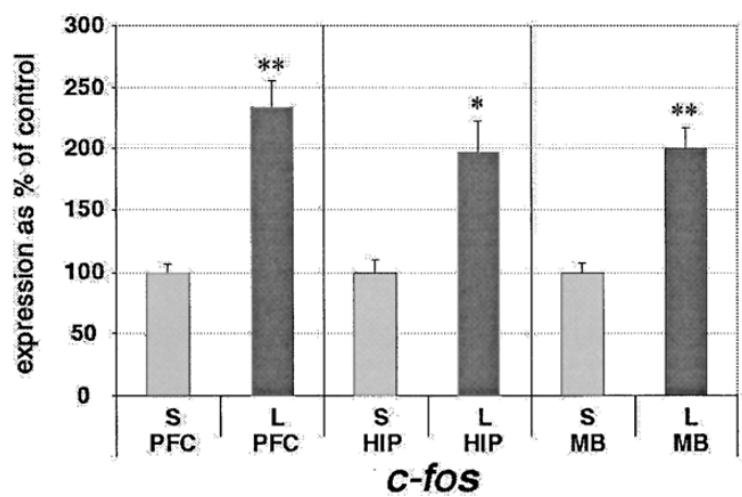

B

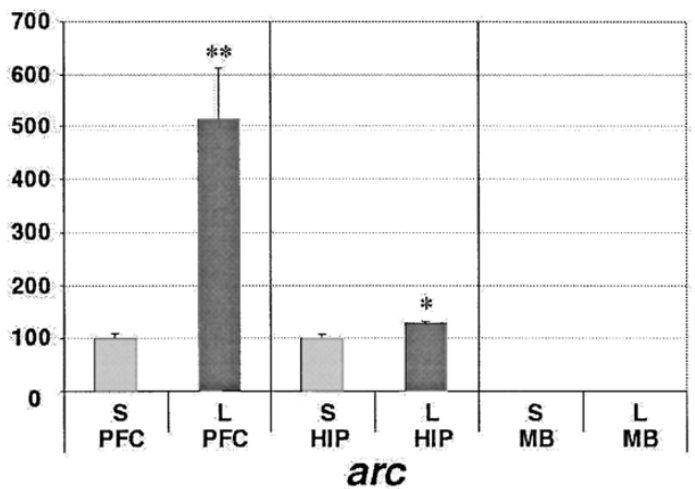

Figure 3. Expression of immediate early genes $c$-fos and arc. (A) Acute LSD induces the expression of $c$-fos $\sim$ twofold in all regions of the brain examined. (B) Acute LSD induces arc expression $\sim$ fivefold in the prefrontal cortex, but doesn't dramatically alter levels in the hippocampus. Arc expression is not detected in the midbrain. L = LSD treated, $\mathrm{S}=$ control. Significance calculated by Students $t$-test $\left({ }^{*} p<.05 ;{ }^{* *} p<.01\right)$.

gene induced by LSD is krox-20, which encodes for a zinc finger transcription factor. Krox-20 contains a $c$-fos serum response element in its promoter region, suggesting that it is co-regulated with c-fos (Chavrier et al. 1989). Krox-20 has been shown to be necessary for normal brain development (Seitanidou et al. 1997) and may be involved in the maintenance of long-term potentiation (Inokuchi et al. 1996). A third nuclear transcription factor induced by LSD is NOR1, a nuclear receptor of the steroid/thyroid family related to NGF1-B/nurr1 (Maruyama et al. 1997; Maruyama et al. 1998). NOR1 expression has been previously shown in vivo only in the brain (Ohkura et al. 1994), however, its expression can be induced in non-neuronal cultures (Bandoh et al. 1995) and is regulated by protein kinase A and protein kinase C. Interestingly, recent reports have suggested that NOR1 may be involved in the response to opiates and cocaine (Werme et al. 1999, 2000).

In addition to nuclear transcription factors, genes encoding for other classes of proteins were induced by LSD administration. Perhaps one of the most interesting of these is arc (activity-regulated cytoskeleton-associated protein). Arc is classified as an immediate early gene because of its rapid induction after stimulation, but unlike c-fos, arc is not a nuclear transcription factor. Arc protein and mRNA are both specifically localized to dendrites, and arc is predicted to be involved in cytoskeletal rearrangements during the process of synaptic plasticity (Lyford et al. 1995). Consistent with this interpretation, antisense inhibition of arc expression leads to impairment of the maintenance phase, but not the induction, of long-term potentiation (Guzowski et al. 2000). LSD produced a robust fivefold increase in arc expression in the prefrontal cortex, similar to that seen with the hallucinogenic drug 1-(2,5-dimethoxy-4-iodophenyl)-2-aminopropane (Pei et al. 2000; Tilakaratne and Friedman 1996). Arc gene expression was not in- creased in the hippocampus by LSD and was not detectable in the midbrain region. This region-specific effect is fascinating in light of the high density of $5-\mathrm{HT}_{2 \mathrm{~A}}$ receptors localized on apical dendrites of pyramidal neurons in the prefrontal cortex (Jakab and GoldmanRakic 1998; Willins et al. 1997). These receptors have been proposed to be the principal targets for hallucinogenic drugs (Aghajanian and Marek 1999a). It is tempting to speculate that upregulation of two genes encoding proteins (arc and Krox-20) linked to synaptic plasticity may represent early sequelae in the pathways that lead to some reported long term effects of LSD use such as Hallucinogen Persisting Perception Disorder (Abraham 1983), and the apparent effectiveness of LSD in the treatment of disorders such as alcohol addiction (Mangini 1998).

An unexpected finding is the induction of the $I \kappa \beta-\alpha$ gene after LSD administration. Ік $\beta-\alpha$ is the main inhibitor of $N F \kappa \beta$, the activating component of the immune response. It is not clear why LSD activates expression of an immune suppressor gene. An intriguing report recently showed that Iк $\beta-\alpha$ is found in the cell bodies and processes of neurons and specifically localizes to the postsynaptic densities, along with NFк $\beta$ (Suzuki et al. 1997). The authors hypothesized that the postsynapti-

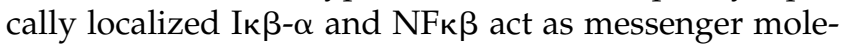
cules that travel from the synapse to the nucleus. Serum glucocorticoid kinase (sgk) is another signaling molecule that is transcriptionally regulated by a variety of stimuli including glucocorticoids, p53, and cell injury (Park et al. 1999). LSD induced a twofold expression of the sgk gene in all three regions examined around two fold. Sgk has been shown to be induced by activation of the ERK MAP kinase pathway, as well as by activation of the glucocorticoid receptor (Mizuno and Nishida 2001). In fact, Mikosz and coworkers concluded that sgk is a survival kinase, as the expression of sgk corre- 


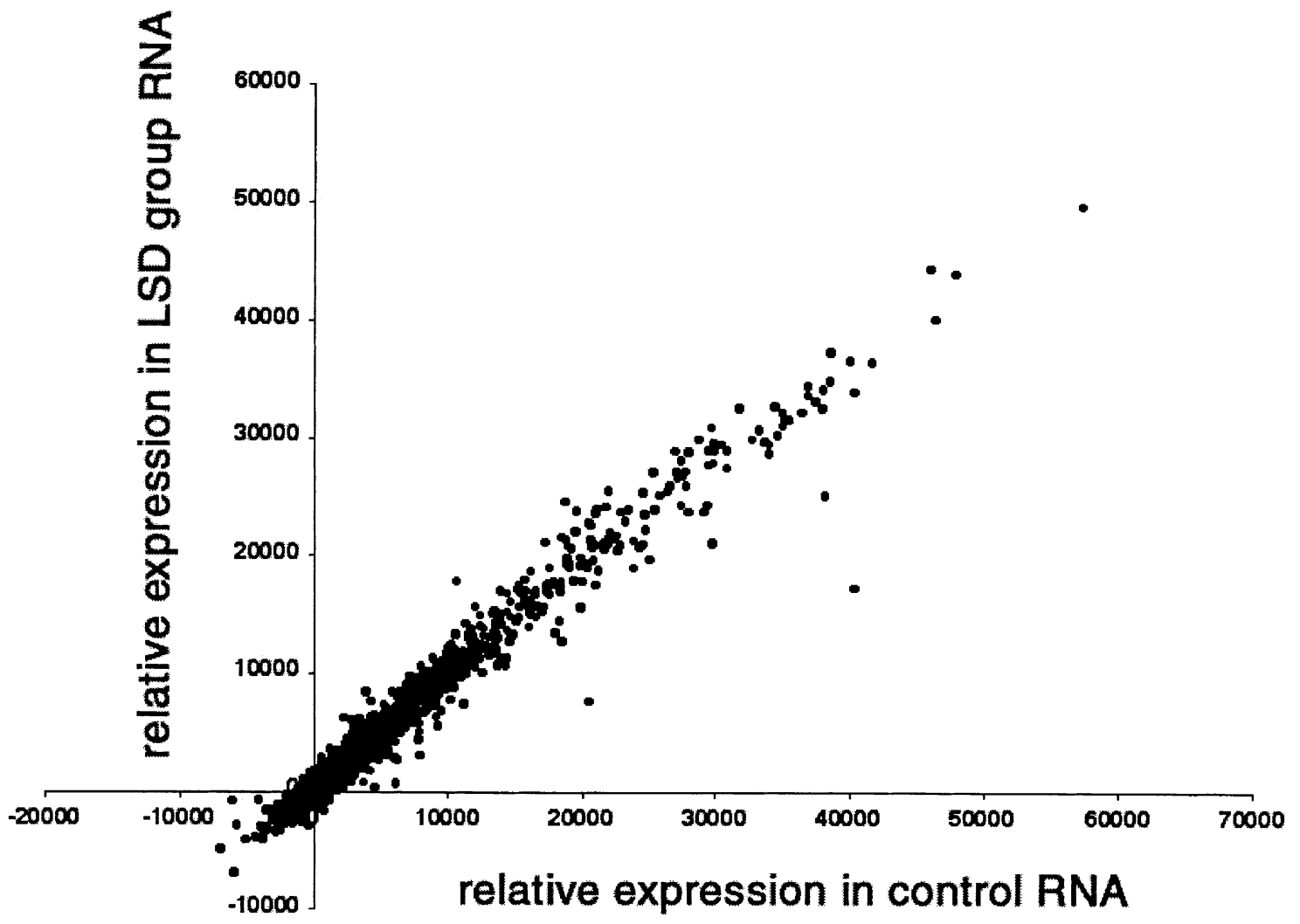

Figure 4. Results of the DNA microarray screen. This scatter plot represents the relative expression of transcripts in the control RNA sample (X-axis) vs. the relative expression of the same transcript in the LSD treatment group RNA (Y-axis). Each point represents the expression data of an individual transcript.

lates directly with protection against apoptosis in certain cell lines (Mikosz et al. 2001). Sgk itself is directly activated by phosphoinositide-3 kinase, and inactivated by PP2A (Park, et al. 1999). Although the downstream targets of sgk are unknown, it has been suggested to phosphorylate and inactivate certain transcription factors in the nucleus, which in turn leads to the promotion of cell survival (Brunet et al. 2001).

Ania3 is the most intriguing transcript that is differentially expressed in light of recent electrophysiological

Table 3. RPA vs. Microarray

\begin{tabular}{lllc}
\hline Gene & & \multicolumn{1}{c}{ RPA } & Microarray \\
\hline sgk & S & $100 \pm 7$ & \\
I $\beta$ & $\mathrm{L}$ & $219 \pm 13$ & $350 \%$ \\
NOR1 & $\mathrm{S}$ & $100 \pm 6$ & \\
& $\mathrm{~L}$ & $171 \pm 7$ & $550 \%$ \\
ania3A & $\mathrm{S}$ & $100 \pm 2$ & \\
\multirow{2}{*}{ Krox-20 } & $\mathrm{L}$ & $145 \pm 11$ & $290 \%$ \\
& $\mathrm{~S}$ & $100 \pm 5$ & $620 \%$ \\
& $\mathrm{~L}$ & $148 \pm 11$ & $310 \%$ \\
\hline
\end{tabular}

studies implicating glutamate receptors in the mechanism of action of hallucinogenic drugs (Aghajanian and Marek 1999b). Ania3 is a splice isoform of homer 1a, only differing slightly at the carboxy terminus. Thus, one would predict that the two proteins perform a similar role within the cell. Homer 1a is a protein that attenuates calcium release mediated by mGluR $_{1 a, 5}$ receptors (Fagni et al. 2000; Xiao et al. 2000), while simultaneously increasing the modulatory influence of these receptors on cationic channels (Kammermeier et al. 2000). Furthermore, proper targeting of group I glutamate receptors to both axons and dendrites has been shown to require homer 1a (Ango et al. 2000). Upregulation of ania3 provides a molecular link between hallucinogens and glutamate receptor signaling.

In conclusion, the present studies represent a novel approach to elucidate further the mechanism of action of hallucinogenic drugs. We have shown that acute LSD treatment increases expression of a small set of genes in the mammalian brain that are involved in a wide array of cellular functions. These apparently divergent pathways may then alter synaptic plasticity, glutamatergic signaling, cytoskeletal architecture and perhaps communication between the synapse and nucleus. Within 

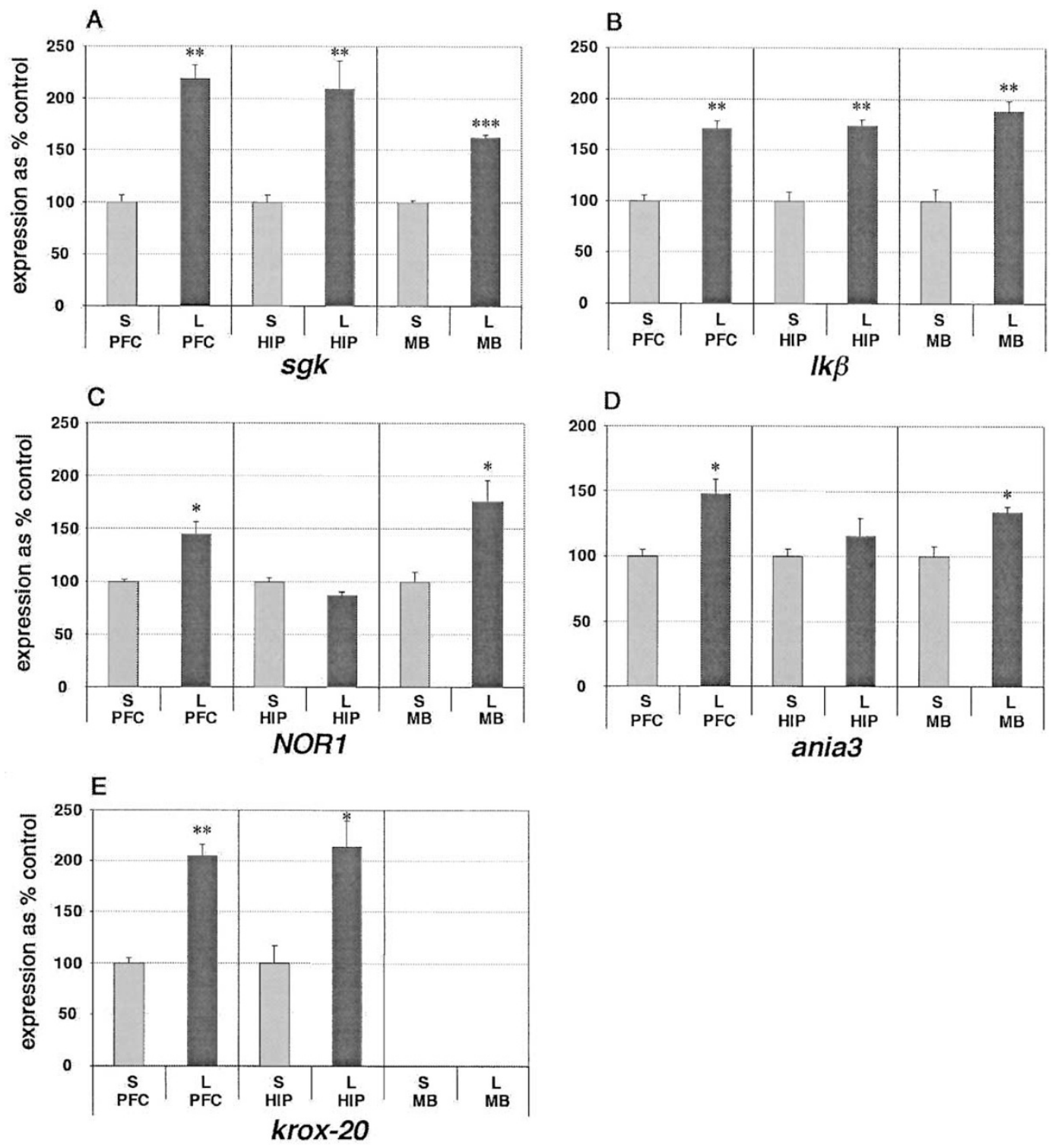

Figure 5. Expression of microarray identified genes. Expression values for each brain region were determined by RNase protection analysis and represent the average of three independent hybridization reactions for four animals pooled for each treatment group. A, Expression of $s g k$. B, Expression of $I \kappa B$. C, Expression of NOR1. D, Expression of ania3. E, Expression of Krox-20. L = LSD treated, $\mathrm{S}=$ control. Significance calculated by Students $t$-test $\left({ }^{*} p<.05 ;{ }^{* *} p<.01 ;{ }^{* * *} p<.001\right)$.

the nucleus, complex patterns of gene expression may be initiated by induction of several different classes of transcription factors. The finding that the expression profiles for some of these genes differed between the prefrontal cortex, hippocampus and thalamic regions of the brain suggest the involvement of different receptor subtypes, with regionalized localization mediating gene expression. Clearly, the range of cellular functions that are regulated by the genes identified in this study begins to give a much broader perspective to understanding how a drug like LSD actually works. Conventional mechanistic studies have up to now essentially focused on acti- vation of serotonin receptors followed by studies of subsequent physiological and intracellular signaling events. The present work has shown that this rather simplistic, though understandable, approach may provide only a narrow window into the actual cellular mechanisms of hallucinogenic drug action. Characterization of genes affected by acute LSD, both in this study, and in future extensions of this work, will lead to a more comprehensive understanding of the action of hallucinogenic drugs such as LSD. These events may not simply be related to the acute mechanism of action of LSD, but may also reflect the beginnings of long-term neuroadaptive processes. 


\section{ACKNOWLEDGMENTS}

The authors wish to thank Efrain Garcia and Lisa Hazelwood for assistance in the secondary validation of expression profiles, and the Vanderbilt Center for Molecular Neuroscience. This research was supported in part by N.I.D.A. grants DA05993 to C.D.N and DA05181 to E.S.B and the Heffter Research Institute.

\section{REFERENCES}

Abraham HD (1983): Visual phenomenology of the LSD Flashback. Arch Gen Psychiat 40:884-889

Aghajanian GK, Marek GJ (1999a): Serotonin and hallucinogens. Neuropsychopharmacology 21:16S-23S

Aghajanian GK, Marek GJ (1999b): Serotonin, via 5-HT2A receptors, increases EPSCs in layer V pyramidal cells of prefrontal cortex by an asynchronous mode of glutamate release. Brain Res 825:161-171

Altmann CR, Bell E, Sczyrba A, Pun J, Bekiranov S, Gaasterland T, Brivanlou AH (2001): Microarray-based analysis of early development in Xenopus laevis. Dev Biol 236:64-75

Ango F, Pin JP, Tu JC, Xiao B, Worley PF, Bockaert J, Fagni L (2000): Dendritic and axonal targeting of type 5 metabotropic glutamate receptor is regulated by homer1 proteins and neuronal excitation. J Neurosci 20:8710-8716

Backstrom JR, Chang MS, Chu H, Niswender CM, SandersBush E (1999): Agonist-directed signaling of serotonin 5-HT2C receptors: differences between serotonin and lysergic acid diethylamide (LSD). Neuropsychopharmacology 21:77S-81S

Bandoh S, Tsukada T, Maruyama K, Ohkura N, Yamaguchi K (1995): Gene expression of NOR-1, a neuron-derived orphan receptor, is inducible in neuronal and other cell lineages in culture. Mol Cell Endocrinol 115:227-230

Breier A (1995): Serotonin, schizophrenia and antipsychotic drug action. Schizophr Res 14:187-202

Brunet A, Park J, Tran H, Hu LS, Hemmings BA, Greenberg ME (2001): Protein kinase SGK mediates survival signals by phosphorylating the forkhead transcription factor FKHRL1 (FOXO3a). Mol Cell Biol 21:952-965

Burris KD, Breeding M, Sanders-Bush E (1991): (+)Lysergic acid diethylamide, but not its nonhallucinogenic congeners, is a potent serotonin 5 HT1C receptor agonist. J Pharmacol Exp Ther 258:891-896

Chavrier P, Janssen-Timmen U, Mattei MG, Zerial M, Bravo R, Charnay P (1989): Structure, chromosome location, and expression of the mouse zinc finger gene Krox-20: multiple gene products and coregulation with the proto- oncogene c-fos. Mol Cell Biol 9:787-797

Fagni L, Chavis P, Ango F, Bockaert J (2000): Complex interactions between mGluRs, intracellular $\mathrm{Ca} 2+$ stores and ion channels in neurons. Trends Neurosci 23:80-88

Freedman DX (1984): LSD: the bridge from human to animal. In Jacobs BL (ed), Hallucinogens: Neurochemical, Behavioral, and Clinical Perspectives. New York, Raven Press, pp 203-226.

Giacomelli S, Palmery M, Romanelli L, Cheng CY, Silvestrini
B (1998): Lysergic acid diethylamide (LSD) is a partial agonist of D2 dopaminergic receptors and it potentiates dopamine-mediated prolactin secretion in lactotrophs in vitro. Life Sci 63:215-222

Guzowski JF, Lyford GL, Stevenson GD, Houston FP, McGaugh JL, Worley PF, Barnes CA (2000): Inhibition of activity-dependent arc protein expression in the rat hippocampus impairs the maintenance of long-term potentiation and the consolidation of long-term memory. J Neurosci 20:3993-4001

Inokuchi K, Murayama A, Ozawa F (1996): mRNA differential display reveals Krox-20 as a neural plasticity- regulated gene in the rat hippocampus. Biochem Biophys Res Commun 221:430-436

Jakab RL, Goldman-Rakic PS (1998): 5-Hydroxytryptamine2A serotonin receptors in the primate cerebral cortex: possible site of action of hallucinogenic and antipsychotic drugs in pyramidal cell apical dendrites. Proc Natl Acad Sci USA 95:735-740

Kammermeier PJ, Xiao B, Tu JC, Worley PF, Ikeda SR (2000): Homer proteins regulate coupling of group I metabatropic glutamate receptors to N-type calcium and M-type potassium channels. J Neurosci 20:7238-7284

Kovacs KJ (1998): c-Fos as a transcription factor: a stressful (re)view from a functional map. Neurochem Int 33:287297

Krebs-Thomson K, Paulus MP, Geyer MA (1998): Effects of hallucinogens on locomotor and investigatory activity and patterns: influence of 5-HT2A and 5-HT2C receptors. Neuropsychopharmacology 18:339-351

Lyford GL, Yamagata K, Kaufmann WE, Barnes CA, Sanders LK, Copeland NG, Gilbert DJ, Jenkins NA, Lanahan AA, Worley PF (1995): Arc, a growth factor and activityregulated gene, encodes a novel cytoskeleton-associated protein that is enriched in neuronal dendrites. Neuron 14:433-445

Mangini M (1998): Treatment of alcoholism using psychedelic drugs: a review of the program of research. J Psychoactive Drugs 30:381-418

Maruyama K, Tsukada T, Bandoh S, Sasaki K, Ohkura N, Yamaguchi K (1997): Expression of the putative transcription factor NOR-1 in the nervous, the endocrine and the immune systems and the developing brain of the rat. Neuroendocrinology 65:2-8

Maruyama K, Tsukada T, Ohkura N, Bandoh S, Hosono T, Yamaguchi K (1998): The NGFI-B subfamily of the nuclear receptor superfamily (review). Int J Oncol 12:1237-1243

Mikosz CA, Brickley DR, Sharkey MS, Moran TW, Conzen SD (2001): Glucocorticoid receptor-mediated protection from apoptosis is associated with induction of the serine/threonine survival kinase gene, sgk-1. J Biol Chem 13:13

Mizuno H, Nishida E (2001): The ERK MAP kinase pathway mediates induction of SGK (serum- and glucocorticoidinducible kinase) by growth factors. Genes Cells 6:261-268

Ohkura N, Hijikuro M, Yamamoto A, Miki K (1994): Molecular cloning of a novel thyroid/steroid receptor superfamily gene from cultured rat neuronal cells. Biochem Biophys Res Commun 205:1959-1965

Park J, Leong ML, Buse P, Maiyar AC, Firestone GL, Hem- 
mings BA (1999): Serum and glucocorticoid-inducible kinase (SGK) is a target of the PI 3- kinase-stimulated signaling pathway. Embo J 18:3024-3033

Pei Q, Lewis L, Sprakes ME, Jones EJ, Grahame-Smith DG, Zetterstrom TS (2000): Serotonergic regulation of mRNA expression of Arc, an immediate early gene selectively localized at neuronal dendrites. Neuropharmacology 39:463-470

Seitanidou T, Schneider-Maunoury S, Desmarquet C, Wilkinson DG, Charnay P (1997): Krox-20 is a key regulator of rhombomere-specific gene expression in the developing hindbrain. Mech Dev 65:31-42

Suzuki T, Mitake S, Okumura-Noji K, Yang JP, Fujii T, Okamoto T (1997): Presence of NF-kappaB-like and IkappaB-like immunoreactivities in postsynaptic densities. Neuroreport 8:2931-2935

Tilakaratne N, Friedman E (1996): Genomic responses to $5-\mathrm{HT}_{1 \mathrm{~A}}$ or $5-\mathrm{HT}_{2 \mathrm{~A} / 2 \mathrm{C}}$ receptor activation is differentially regulated in four regions of rat brain. Eur J Pharmacol 307:211-217

Titeler M, Lyon RA, Glennon RA (1988): Radioligand binding evidence implicates the brain $5-\mathrm{HT} 2$ receptor as a site of action for LSD and phenylisopropylamine hallucinogens. Psychopharmacology 94:213-216

Watson SJ, Meng F, Thompson RC, Akil H (2000): The "chip" as a specific genetic tool. Biol Psychiatry 48:1147-1156

Watts VJ, Lawler CP, Fox DR, Neve KA, Nichols DE, Mailman RB (1995): LSD and structural analogs: pharmacological evaluation at D1 dopamine receptors. Psychopharmacology 118:401-409

Werme M, Olson L, Brene S (2000): NGFI-B and nor1 mRNAs are upregulated in brain reward pathways by drugs of abuse: different effects in Fischer and Lewis rats. Brain Res Mol Brain Res 76:18-24

Werme M, Thoren P, Olson L, Brene S (1999): Addictionprone Lewis but not Fischer rats develop compulsive running that coincides with downregulation of nerve growth factor inducible-B and neuron-derived orphan receptor 1. J Neurosci 19:6169-6174

Willins DL, Deutch AY, Roth BL (1997): Serotonin 5-HT2A receptors are expressed on pyramidal cells and interneurons in the rat cortex. Synapse 27:79-82

Xiao B, Tu JC, Worley PF (2000): Homer: a link between neural activity and glutamate receptor function. Curr Opin Neurobiol 10:370-374 